\title{
PENGARUH SEXUAL HARASSMENT TERHADAP TURNOVER INTENTION MELALUI JOB SATISFACTION PADA KARYAWAN PERHOTELAN DI SURABAYA
}

\author{
Putri Widiana \\ Universitas Negeri Surabaya \\ putri.17080574072@mhs.unesa.ac.id \\ Budiono \\ Universitas Negeri Surabaya \\ ec.budiono@unesa.ac.id
}

Abstract

Sexual harassment has become a global problem. Previous research has revealed that many negative impacts can be caused and affect the condition of someone who is sexually harassed. This study aimed to investigate the effect of sexual harassment on turnover intention and examine the mediating role of job satisfaction among hotel employees in Surabaya. A total of 32 hotel employees participated through a purposive non-probability sampling technique. This research uses partial least square (PLS) as its statistical analysis. The results showed a significant positive relationship between sexual harassment with turnover intention. Sexual harassment has a negative effect on job satisfaction, and job satisfaction has a negative effect on turnover intention Results also indicate that job satisfaction plays the mediator role between sexual harassment and turnover intention among Surabaya hotel employees.

Keywords: job satisfaction; sexual harassment; turnover intention.

\section{PENDAHULUAN}

Kunci keberhasilan dalam bisnis adalah kemampuanuntuk memertahankan loyalitas para pemangku kepentingan yang tidak hanya mencakup pelanggan tetapi juga karyawan (Javier, 2011). Maka dari itu, cara untuk memertahankan karyawan yang kompeten patut diperhatikan sehingga dapat menekan tingkat turnover di perusahaan. Menurut Lu et al. (2016), perputaran karyawan yang tinggi tidak hanya memengaruhi keuangan secara langsung, tetapi juga menghasilkan banyak dampak negatif seperti kinerja organisasi yang rendah, produktivitas yang rendah, moral yang rendah dan gangguan layanan, yang mengakibatkan ketidakpuasan pelanggan. Hasil survei Mercer Singapore pada gambar 1, terlihat bahwa adanya peningkatan turnover rate negara-negara di Asia jika dibandingkan dengan tahun sebelumnya, hal ini selain dipengaruhi oleh adanya pandemi covid-19 yang mengharuskan adanya perampingan tenaga kerja juga dipengaruhi oleh faktor lain (Mercer.com, 2020).

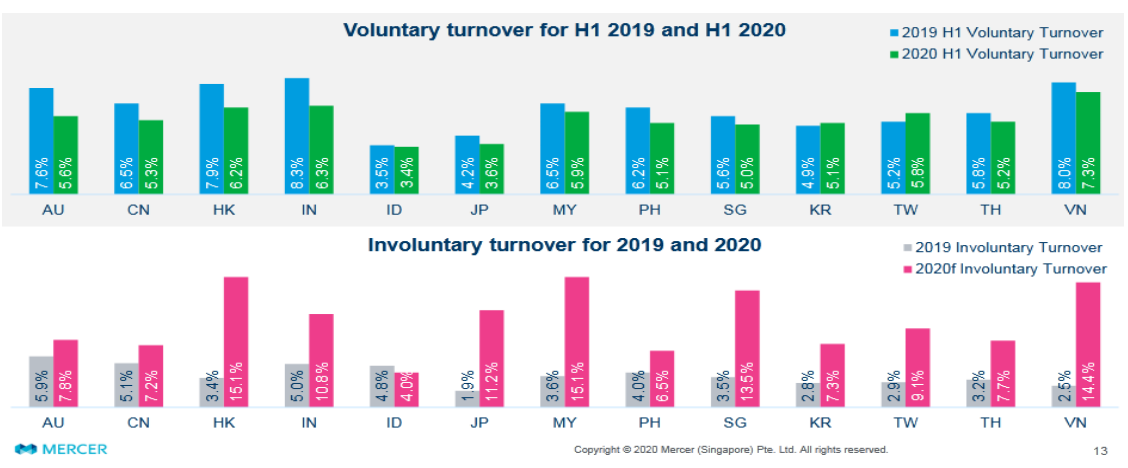

Sumber: Mercer Singapore (2020)

Gambar 1. TURNOVER RATE 2019-2020

Ada banyak faktor yang memengaruhi turnover intention, salah satunya adalah perlakuan sexual harassment di tempat kerja (Merkin, 2008). Survei kuantitatif yang diselenggarakan Never Okay x Scoop Asia pada 19 November hingga 9 Desember 2018, dengan responden berasal dari beragam 
Putri Widiana \& Budiono. Pengaruh Sexual Harassment terhadap Turnover Intention melalui Job Satisfaction pada Karyawan Perhotelan di Surabaya

sektor kerja di Indonesia menunjukkan bahwa dari total 1.240 responden, 81,29\% diantaranya mengalami sexual harassment di tempat kerja (Nurvitasari, 2018). Sexual harassment didefinisikan sebagai rayuan seksual yang tidak diinginkan, permintaan bantuan seksual, dan perilaku verbal atau fisik lainnya yang bersifat seksual yang mengganggu pekerjaan atau kinerja seseorang serta menciptakan lingkungan kerja yang kurang nyaman (Hejase, 2015). Sexual harassment secara positif memiliki hubungan dengan turnover intention (Merkin, 2008). Hal serupa dikemukakan oleh Salman et al. (2016) yang menunjukkan bahwa adanya hubungan antara sexual harassment di tempat kerja dengan turnover intention. Hal lain diungkapkan Scheinder et al. (1997) dan Badawy (2016) sexual harassment dan turnover intention memiliki hubungan dengan signifikasi yang rendah.

Hal lain yang dapat memengaruhi turnover intention adalah job satisfaction (Lu et al., 2017). Perubahan kondisi lingkungan organisasi baik internal maupun eksternal secara langsung maupun tidak langsung dapat menurunkan tingkat job satisfaction, sehingga dapat menimbulkan turnover intention pada karyawan dan pada akhirnya dapat menimbulkan turnover yang sebenarnya (Nazenin \& Palupiningdyah, 2014). Job satisfaction memainkan peran penting dalam menarik dan memertahankan kemampuan karyawan dalam suatu organisasi, individu dengan tingkat job satisfaction yang tinggi akan memiliki catatan fisik dan psikologis lebih sehat, yang sangat mungkin menghasilkan produktivitas dan efektivitas lebih tinggi dalam kinerja dan akan bertahan lebih lama dalam organisasi (Jehanzeb \& Mohanty, 2018). Youcef et al. (2016); Fah et al. (2010) menyatakan bahwa terdapat pengaruh signifikan negatif antara job satisfaction terhadap turnover intention. Job satisfaction dan turnover intention memiliki pengaruh signifikan negatif (Jehanzeb et al. 2015; Sidharta \& Margaretha, 2011; Carmeli \& Weisberg 2006; Shah \& Jumani 2015; Li et al. 2019). Berbeda dengan Yuda et al. (2017) yang mengemukakan job satisfaction berpengaruh tidak signifikan terhadap turnover intention. Sejalan dengan Yuda et al. (2017), Witasari (2009) menyatakan job satisfaction secara statistik terbukti tidak berpengaruh signifikan terhadap turnover intention.

Malik et al. (2014) menyatakan job satisfaction juga bisa dipengaruhi oleh sexual harassment, dampak dari sexual harassment di tempat kerja meningkatkan kecemasan dan memengaruhi kinerja mereka yang pada akhirnya berdampak negatif pada job satisfaction. Hutagalung \& Ishak (2012) mengemukakan bahwa sexual harassment menjadi prediktor yang signifikan terhadap penurunan job satisfaction dan peningkatan stres kerja di tempat kerja. Menurut Antecol \& Clark (2006), seseorang yang memiliki pengalaman sexual harassment memiliki tingkat job satisfaction secara keseluruhan yang lebih rendah. Hal berbeda didapat oleh Pranantya (2016) yang menyatakan bahwa sexual harassment tidak berpengaruh terhadap job satisfaction serta Merkin (2008) yang mengungkapkan job satisfaction tidak terlalu signifikan dipengaruhi oleh sexual harassment.

Sexual harassment bisa terjadi di mana saja, namun kerap terjadi pada banyak orang di industri perhotelan. Industri perhotelan sangat rentan terhadap insiden pelecehan seksual karena karakteristiknya, termasuk ambiguitas "layanan perhotelan", jam dan kondisi kerja yang tidak biasa, interaksi orang-orang dalam penyampaian layanan, dan praktik personalia yang masih harus diperbaiki (Eller, 1990). Adanya sexual harassment nantinya akan berakibat pada keuangan perusahaan, menurunya job satisfaction karyawan dan meningkatkan turnover (Salman et al.,2016). Akan tetapi, hal lain diungkapkan beberapa karyawan perhotelan di Surabaya yang pernah mengalami sexual harassment dalam wawancara tidak terstruktur, mereka mengaku memilih untuk tetap bekerja di tempat yang sama meskipun mendapatkan pengalaman sexual harassment. Hal tersebut dikarenakan keadaan faktor ekonomi, mereka berfikir akan kesulitan mendapatkan pekerjaan yang baru di tengah pandemi covid-19, selain itu juga dikarenakan adanya rasa takut dan malu. Penelitian ini menganalisis pengaruh sexual harassment terhadap turnover intention dan peran job satisfaction sebagai mediator antara kedua variabel tersebut pada karyawan perhotelan di Surabaya.

\section{KAJIAN PUSTAKA DAN PENGEMBANGAN HIPOTESIS}

\section{Sexual Harassment}

Hejase (2015) mendefinisikan sexual harassment sebagai rayuan seksual yang tidak diinginkan, baik secara fisik maupun verbal. Sexual harassment dalam bentuk verbal meliputi gurauan atau pesan 
seksual, ajakan kencan terus menerus walaupun telah ditolak, komentar merendahkan, ungkapan sexist mengenai bentuk tubuh, pakaian atau aktivitas seksual, serta permintaan pelayanan seksual dengan ancaman. Dalam bentuk godaan fisik di antaranya adalah tatapan yang sugestif terhadap bagian-bagian tubuh, lirikan yang menggoda, meraba, mencium, dan mendekap (Kurnianingsih, 2003). Perilaku pelecehan seksual lebih mengacu pada perilaku ofensif, bukan insiden (Schneider et al., 1997). Berdasarkan situasinya, Badawy (2016) membedakan sexual harassment menjadi dua, yang pertama adalah situasi quid pro quo, di mana orang yang memiliki otoritas menuntut perhatian seksual sebagai imbalan atas tunjangan yang diberikan dan kondisi situasi kerja, di mana seseorang menjadi sasaran sexual harassment berulang atau undangan seksual tanpa disertai dengan adanya tunjangan. Pengalaman sexual harassment dikaitkan dengan efek negatif, seperti penurunan job satisfcation, komitmen organisasi yang lebih rendah, tingkat turnover yang lebih tinggi, kesehatan fisik maupun mental yang buruk bahkan gejala post-traumatic stress disorder (PTSD) (Willness et al., 2007).

\section{Turnover Intention}

Aydogdu \& Asikgil (2015) mengartikan turnover intention sebagai sikap perilaku seseorang untuk menarik diri dari organisasi. Turnover intention menjadi faktor terkuat yang memengaruhi turnover (Cho \& Lewis 2011). Turnover dapat dibedakan menjadi dua yaitu voluntary turnover dan involuntary turnover (Robbins, 2003:215). Voluntary turnover mencerminkan keputusan karyawan untuk meninggalkan organisasi. Sedangkan involuntary turnover atau penghentian, memiliki konsekuensi dan biaya tersendiri. Turnover yang tinggi mencerminkan perekrutan yang buruk serta keputusan yang harus diperbaiki (Shaw et al., 1998). Keadaan tersebut akan berakibat pada keuangan organisasi, kinerja dan produktivitas rendah yang berakibat pada menurunnya kepuasan konsumen (Lu et al., 2016). Di sisi lain turnover akan menguntungkan organisasi apabila karyawan yang keluar merupakan karyawan yang tidak produktif.

\section{Job Satisfaction}

Job satisfaction adalah keadaan emosional menyenangkan yang dihasilkan dari penilaian seseorang pada pekerjaannya (Sijabat, 2011). Job satisfaction merupakan faktor penting dan salah satu perhatian utama dalam organisasi. Job satisfaction merupakan serangkaian perasaan dan emosi positif yang dirasakan oleh karyawan tentang pekerjaan mereka (Tarigan \& Ariani, 2015). Karyawan akan lebih puas dengan pekerjaan dan organisasi jika mereka menganggap lingkungan kerja kondusif, memuaskan, dan bermanfaat secara materi (Jehanzeb \& Mohanty, 2018). Seseorang dengan tingkat job satisfaction yang tinggi akan menunjukkan sikap positif terhadap pekerjaanya (Sidharta \& Margaretha, 2011). Job satisfaction biasanya dinyatakan dengan sikap. Seorang yang merasa puas terhadap pekerjaannya akan tercermin pada sikapnya, misalnya karyawan akan semakin loyal terhadap organisasinya (Luthans, 2011:141).

\section{Hubungan Antar Variabel}

Karyawan cenderung menghindari lingkungan kerja yang tidak nyaman, dan salah satu faktor yang memengaruhi ketidaknyamanan tersebut adalah sexual harassment (O'Connell \& Korabik, 2000). Literatur stres dan coping menunjukkan bahwa strategi paling umum yang digunakan untuk mengatasi sexual harassment adalah berpindah (Sims et al., 2005). Penelitian yang mendukung pernyataan tersebut adalah Mueller et al. (2001), Salman et al. (2016), dan Kirlioğlu \& Toygar (2020) yang menunjukkan bahwa sexual harassment di tempat kerja akan meningkatkan turnover intention pada karyawan.

\section{H1: Ada pengaruh positif antara sexual harassment terhadap turnover intention.}

Sexual harassment yang terjadi di tempat kerja bukan hanya memengaruhi tingkat turnover intention, namun juga berdampak negatif pada job satisfaction (Rahim, 2005). Job satisfaction merupakan hal yang sangat penting di tempat kerja karena memiliki efek yang berhubungan dengan kesehatan dan kesejahteraan karyawan (Willness et al., 2007). Karyawan yang mengalami sexual harassment memiliki tingkat job satisfaction dan stres kerja yang lebih tinggi dibanding mereka yang tidak 
Putri Widiana \& Budiono. Pengaruh Sexual Harassment terhadap Turnover Intention melalui Job Satisfaction pada Karyawan Perhotelan di Surabaya

mengalami (Hutagalung \& Ishak, 2012). Penelitian lain yang mendukung pernyataan tersebut antara lain Antecol \& Clark (2006) dan Malik et al. (2014) yang mengungkapkan seorang karyawan yang mengalami sexual harassment akan memiliki tingkat job satisfaction yang rendah.

H2: Ada pengaruh negatif antara sexual harassment terhadap job satisfaction.

Individu dengan tingkat job satisfaction yang tinggi akan bertahan lebih lama dalam organisasi (Jehanzeb \& Mohanty, 2018). Semakin tidak puas karyawan, semakin besar kemungkinan mereka untuk memertimbangkan peluang kerja lain, hal ini menyiratkan bahwa setiap unit penurunan kepuasan kerja mencerminkan peningkatan niat untuk berpindah (Carmeli \& Weisberg, 2006). Karyawan yang puas lebih mungkin untuk berkomitmen pada organisasi mereka dan menurunkan niat untuk berhenti dari pekerjaan (Fah et al., 2010). Penelitian yang mendukung pernyataan tersebut antara lain Sidharta \& Margaretha, (2011), Nazenin \& Palupiningdyah (2014), Shah \& Jumani (2015), dan Youcef et al. (2016) yang menyatakan bahwa job satisfaction memiliki korelasi yang bersifat negatif terhadap turnover intention.

H3: Ada pengaruh negatif antara job satisfaction terhadap turnover intention.

Temuan Long et al. (2016) menjelaskan bahwa ada hubungan negatif yang signifikan antara sexual harassment dan job satisfaction dalam organisasi (baik perilaku sexual harassment secara verbal maupun perilaku fisik). Selain itu, menurut Lu et al. (2017), Jehanzeb et al. (2015), dan Li et al. (2019) job satisfaction akan memengaruhi tingkat turnover intention karyawan. Dari beberapa studi tersebut, diketahui bahwa sexual harassment berpengaruh terhadap job satisfaction dan job satisfaction berpengaruh terhadap turnover intention.

H4: Ada pengaruh antara sexual harassment terhadap turnover intention melalui job satisfaction.



Sumber: Data diolah, 2021

Gambar 1. KERANGKA KONSEPTUAL

\section{METODE PENELITIAN}

Penelitian ini merupakan penelitian kausalitas, yang menganalisis variabel bebas sexual harassment terhadap variabel terikat turnover intention melalui variabel mediasi job satisfaction dengan pendekatan kuantitatif. Sumber data primer berasal dari kuesioner online dengan menggunakan skala likert 1-4 dan wawancara tidak terstruktur. Populasi dari penelitian ini adalah karyawan perhotelan di kota Surabaya yang pernah mengalami sexual harassment. Sampel yang digunakan sebanyak 32 responden karyawan yang telah memenuhi syarat inklusi dan eksklusi berdasarkan pernyataan yang ada pada kuesioner. Menggunakan teknik non-probability sampling dengan jenis purposive sampling. Data yang terkumpul selanjutnya dianalisis menggunakan Structural Equation Modeling (SEM) dengan aplikasi SmartPLS 3.0.

\section{HASIL DAN PEMBAHASAN}

Tabel 1 menunjukkan karakteristik responden berdasarkan jenis kelamin, usia, status pernikahan, dan pendidikan terakhir. 
Tabel 1.

KARAKTERISTIK RESPONDEN

\begin{tabular}{llcc}
\hline Variabel Demogarfis & Kategori & Frekuensi & Persentase \\
\hline Jenis kelamin & Laki-laki & 10 & $31 \%$ \\
\multirow{3}{*}{ Usia } & Perempuan & 22 & $69 \%$ \\
Status Pernikahan & 17-24 tahun & 25 & $78 \%$ \\
\multirow{3}{*}{ Pendidikan terakhir } & 25-32 tahun & 7 & $22 \%$ \\
& Menikah & 4 & $12,5 \%$ \\
& Belum menikah & 28 & $87,5 \%$ \\
& SMA & 10 & $31.3 \%$ \\
& SMK & 9 & $28,1 \%$ \\
& D3 & 3 & $9,4 \%$ \\
& D4 & 1 & $3,1 \%$ \\
& S1 & 9 & $28,1 \%$ \\
\hline
\end{tabular}

Sumber: Data diolah, 2021

\section{Validitas Konvergen}

Gambar 2 menunjukkan nilai outer loading keseluruhan indikator $\geq 0,5$ sehingga indikator dikatakan valid.

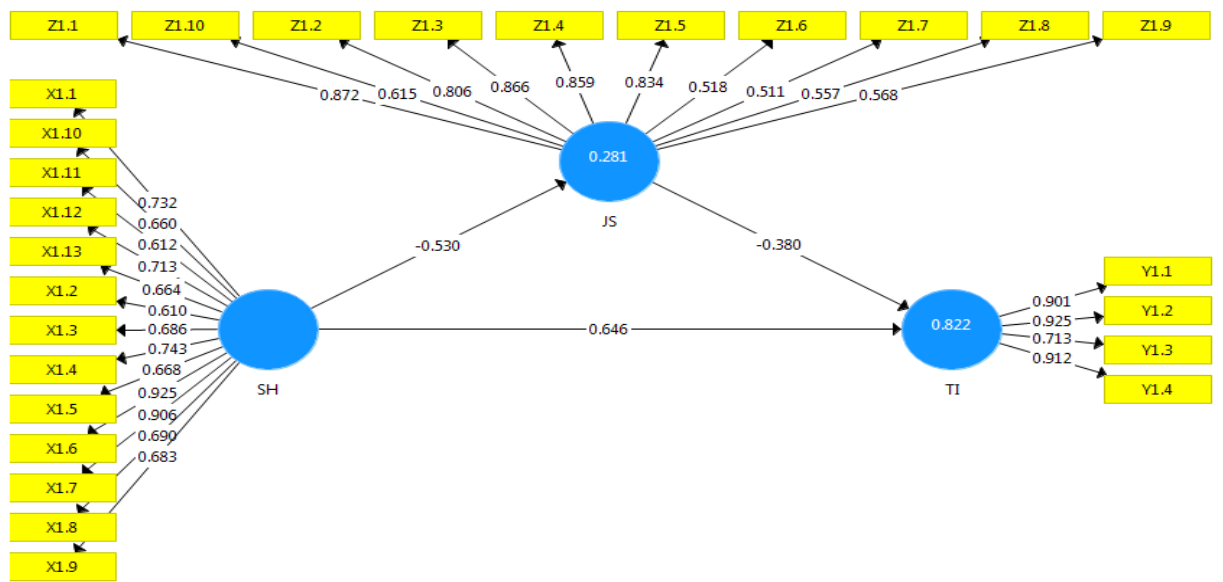

Sumber: Hasil SmartPLS (2021)

Gambar 2. MEASUREMENT MODEL

Tabel 2.

AVE, COMPOSITE RELIABILITY, DAN CRONBACH'S ALPHA

\begin{tabular}{lccc}
\hline \multicolumn{1}{c}{ Variabel } & AVE & Composite Reliability & Cronbach's Alpha \\
\hline Sexual Harassment & 0,519 & 0,932 & 0,920 \\
Turnover Intention & 0,752 & 0,923 & 0,886 \\
Job Satisfaction & 0,513 & 0,910 & 0,887 \\
\hline
\end{tabular}

Sumber: Hasil SmartPLS (2021)

\section{Validitas Diskriminan}

Tabel 2 menunjukkan perbandingan nilai AVE antar variabel $\geq 0,5$. Maka variabel dikatakan valid dan memiliki keunikan satu sama lain.

\section{Composite Reliability}

Tabel 2 menunjukkan nilai composite reliability $\geq 0,7$. Maka keseluruhan variabel dikatakan reliabel.

\section{Cronbach Alpha}

Tabel 2 menunjukkan nilai cronbach's alpha $\geq 0,7$. Maka keseluruhan variabel memiliki reliabilitas yang baik. 
Putri Widiana \& Budiono. Pengaruh Sexual Harassment terhadap Turnover Intention melalui Job Satisfaction pada Karyawan Perhotelan di Surabaya

\section{Analisis R-Square}

Nilai R-Square pengaruh sexual harassment terhadap job satisfaction sebesar 0,281. Hal tersebut dapat diinterpretasikan variabel sexual harassment mampu menjelaskan variabel job satisfaction sebanyak 28,1\%, variabel lainnya yang tidak disebutkan sanggup menerangkan job satisfaction sejumlah 71,9\%. Nilai R-Square variabel turnover intention sebesar 0,822. Dapat diinterpreasikan variabel independen sexual harassment mampu menjelaskan variabel turnover intention sebanyak $82,2 \%$, sedangkan variabel lain yang tidak disebutkan dapat menjelaskan pengaruhnya sebesar $17,8 \%$.

\section{Uji Signifikasi}

Tabel 3 menunjukkan nilai hubungan antar variabel

\section{Tabel 3.}

\section{PENGARUH LANGSUNG DAN TIDAK LANGSUNG}

\begin{tabular}{lcccc}
\hline Hubungan Variabel & Original Sample & T-Statitstics & Informasi & Kesimpulan \\
\hline $\mathrm{SH} \rightarrow \mathrm{TI}$ & 0,646 & 6,266 & $\geq 1,96$ & Hipotesis Diterima \\
$\mathrm{SH} \rightarrow \mathrm{JS}$ & $-0,530$ & 4,658 & $\geq 1,96$ & Hipotesis Diterima \\
$\mathrm{JS} \rightarrow \mathrm{TI}$ & $-0,380$ & 3,650 & $\geq 1,96$ & Hipotesis Diterima \\
$\mathrm{SH} \rightarrow \mathrm{JS} \rightarrow \mathrm{TI}$ & 0,202 & 2,356 & $\geq 1,96$ & Hipotesis Diterima \\
\hline
\end{tabular}

Sumber: Hasil SmartPLS (2021)

Berdasarkan tabel 3 T-statistik pengaruh variabel sexual harassment terhadap variabel turnover intention sebesar $6,266 \geq 1,96$ (t-tabel) yang diartikan terdapat pengaruh signifikan. Nilai original sample menunjukkan nilai negatif sebesar 0,646 yang menunjukkan bahwa hubungan variabel sexual harassment terhadap variabel turnover intention adalah positif. Nilai variabel sexual harassment terhadap job satisfaction sebesar 4,658 $\geq 1,96$ (t-tabel), hal tersebut diartikan adanya pengaruh signifikan antara kedua variabel tersebut. Original sample -0,530 yang menunjukkan arah hubungan kedua variabel tersebut adalah negatif. Variabel job satisfaction terhadap turnover intention memiliki nilai 3,650 $\geq 1,96$ (t-tabel), hal ini menunjukkan adanya pengaruh yang signifikan. Nilai original sample sebesar $-0,380$ dan dapat diartikan bahwa hubungan antara kedua variabel adalah negatif.

Nilai $t$-statistic hubungan antar variabel sexual harassment terhadap turnover intention melalui job satisfaction sebesar 2,356 $\geq 1,96$ (t-tabel), yang berarti adanya pengaruh signifikan sexual harassment terhadap turnover intention melalui job satisfaction. Nilai koefisien indirect effect sebesar 0,202 sedangkan nilai koefisien direct effect variabel sexual harassment terhadap turnover intention sebesar 0,646 .

\section{Pengaruh Sexual Harassment terhadap Turnover Intention}

Dari hasil analisis variabel sexual harassment berpengaruh signifikan positif terhadap variabel turnover intention. Dapat diartikan bahwa semakin tinggi tingkat sexual harassment yang dialami karyawan industri perhotelan di Surabaya, semakin tinggi pula tingkat turnover intention yang dimiliki. Berpengaruhnya sexual harassment terhadap turnover intention sejalan dengan Sims et al. (2005) pada penelitiannya terhadap tentara wanita departemen pertahanan Amerika Serikat yang mengungkapkan sexual harassment memiliki pengaruh positif terhadap turnover intention atau niat karyawan untuk meninggalkan pekerjaan mereka. Dalam penelitian ini, karyawan perhotelan di Surabaya yang mengalami sexual harassment akan cenderung sering memiliki pikiran untuk berpindah ataupun mulai sering mencari alternatif pekerjaan lain. Hal tersebut merupakan salah satu metode coping yang paling umum dilakukan oleh seseorang yang mengalami sexual harassment Sims et al. (2005). Studi ini juga diperkuat oleh Malik et al. (2014) dan Salman et al. (2016) pada penelitiannya terhadap 127 orang pada sekolah bisnis negeri maupun swasta di Peshawar Pakistan, yang menunjukkan bahwa memang ada hubungan signifikan positif antara sexual harassment di tempat kerja dengan turnover intention.

\section{Pengaruh Sexual Harassment terhadap Job Satisfaction}

Hasil analisis membuktikan variabel sexual harassment memiliki pengaruh signifikan negatif terhadap job satisfaction. Semakin tinggi tingkat sexual harassment yang dialami karyawan industri 
perhotelan di Surabaya, maka semakin rendah tingkat job satisfaction yang mereka miliki. Hasil tersebut didukung oleh Willness et al. (2007) yang mengemukakan bahwa sexual harassment memiliki pengaruh signifikan negatif terhadap job satisfaction, secara keseluruhan, dan tanpa terkecuali seseorang yang mengalami sexual harassment memiliki perasaan yang terpengaruh secara negatif tentang pekerjaan mereka. Hal itu dapat dikarenakan adanya rasa tidak nyaman karena kurang baiknya hubungan dengan rekan kerja, atasan, maupun pelanggan akibat adanya perlakuan sexual harassment yang diterima. Sesuai dengan hasil kuesioner, nilai terendah faktor yang memengaruhi job satisfaction adalah supervision dan co-worker sedangkan perlakuan yang paling banyak diterima oleh karyawan perhotelan di Surabaya adalah gender harassment. Gender harassment sejauh ini merupakan jenis pelecehan seksual yang paling umum. Hal ini mengacu pada berbagai perilaku verbal dan nonverbal yang tidak ditujukan untuk "kerja sama" seksual tetapi menyampaikan sikap menghina, bermusuhan, dan merendahkan anggota dari satu jenis kelamin (Leskinen et al., 2011). Keadaan ini nantinya akan memengaruhi tingkat kepuasan karyawan. Studi ini juga diperkuat juga oleh penelitian Malik et al. (2014) dan Hutagalung \& Ishak, (2012) yang menunjukkan sexual harassment berpengaruh negatif terhadap job satisfaction seseorang.

\section{Pengaruh Job Satisfaction terhadap Tunover Intention}

Dari hasil analisis membuktikan variabel job satisfaction berpengaruh signifikan negatif terhadap variabel turnover intention. Di mana semakin tinggi tingkat job satisfaction karyawan perhotelan di Surabaya, maka akan semakin rendah tingkat turnover intention yang mereka miliki. Adanya pengaruh secara signifikan negatif antara job satisfaction terhadap turnover intention sejalan dengan penelitian Carmeli \& Weisberg (2006) terhadap karyawan bagian keuangan, pekerja sosial yang bekerja di sektor publik, dan pengacara sektor swasta di Israel. Adanya ketidaksesuaian antara ekspektasi karyawan dengan keadaan aktual yang diterima, dapat menjadi faktor yang memengaruhi tingkat kepuasan mereka terhadap pekerjaan. Dalam penelitian ini, faktor kepuasan yang memiliki nilai rendah adalah hubungan karyawan perhotelan di Surabaya dengan supervison dan co-worker. Kurang baiknya hubungan antar sesama karyawan maupun dengan pimpinan, dapat menyebabkan rendahnya tingkat job satisfaction. Rendahnya tingkat job satisfaction yang dimiliki akan berpengaruh pada niat mereka untuk berpindah. Hasil ini juga sejalan dengan Fah et al. (2010), Sidharta \& Margaretha (2011), Nazenin \& Palupiningdya (2014), Shah \& Jumani (2015), Youcef et al. (2016), $\mathrm{Lu}$ et al. (2017), dan Jehanzeb et al. (2015) yang mengemukakan adanya pengaruh negatif signifikan antara job satisfaction seorang karyawan dengan tingkat turnover intention yang mereka miliki.

\section{Pengaruh Sexual Harassment terhadap Turnover Intention melalui Job Satisfaction}

Hasil analisis membuktikan variabel job satisfaction memiliki peran sebagai mediator. Penelitian ini juga didukung dengan wawancara online tidak terstruktur yang dilakukan pada salah satu responden, yang mengungkapkan bahwa "Saya merasa tidak nyaman dan direndahkan dengan perlakuan yang saya dapatkan, jadi sering punya pikiran buat keluar". Keadaan lingkungan kerja yang kurang nyaman karena adanya pengalaman sexual harassment, membuat mereka merasakan adanya gap antara ekspektasi yang mereka harapkan ketika bekerja dengan keadaan aktual yang terjadi, hal itu menimbulkan niat untuk segera meninggalkan pekerjaan saat ini sering terlintas. Shah \& Jumani (2015) mengemukakan bahwa lingkungan memiliki dampak signifikan terhadap kebahagiaan pekerja. Kepuasan kerja seorang pekerja lebih bergantung pada faktor-faktor lingkungan (Tella, 2007). Keadaan lingkungan kerja yang nyaman akan memengaruhi tingkat job satisfaction menjadi lebih tinggi, sehingga membuat tingkat turnover intention yang dimiliki karyawan lebih rendah.

\section{KESIMPULAN}

Setelah dilakukan studi pada karyawan perhotelan di kota Surabaya, maka dapat disimpulkan bahwa, semakin tinggi tingkat sexual harassment yang dialami maka akan semakin tinggi juga tingkat turnover intention yang dimiliki. Sexual harassment juga memengaruhi tingkat job satisfaction, semakin sering karyawan mengalami sexual harassment maka akan berpengaruh pada rendahnya tingkat job satisfaction, dan tingkat job satisfaction yang rendah akan memengaruhi tingginya 
Putri Widiana \& Budiono. Pengaruh Sexual Harassment terhadap Turnover Intention melalui Job Satisfaction pada Karyawan Perhotelan di Surabaya

turnover intention. Sedangkan sexual harassment memiliki pengaruh tidak langsung terhadap turnover intention melalui job satisfaction.

Beberapa saran yang dapat diberikan adalah, perbaikan implementasi kebijakan yang diberlakukan manajemen, kebijakan tersebut harus diterapkan dari lini bawah hingga atas tanpa pengecualian. Sistim pengamanan 24 jam penuh dan tanggap serta pemberian sanksi yang tegas pun harus diterapkan. Selain itu pihak manajemen bisa memberikan sosialisasi tentang sexual harassment sehingga karyawan bisa lebih aware dan paham apa saja yang harus dilakukan jika mengalaminya. Selanjutnya perusahaan dapat menerapkan Employee Assistance Program (EAP) untuk membantu menangani masalah sexual harassment yang dialami oleh karyawan perhotelan yang dapat berdampak pada menurunnya tingkat job satisfaction dan adanya niat untuk berpindah.

Keterbatasan utama penelitian ini adalah responden, kebanyakan karyawan yang pernah mengalami sexual harassment lebih sulit untuk memberikan pendapatnya karena merasa malu pernah menjadi korban, sehingga responden yang bersedia untuk memberikan pendapatnya masih dalam jumlah yang kecil. Penelitian selanjutnya diharapkan dapat menggunakan jumlah sampel yang lebih besar dengan proporsi antara karyawan laki-laki dan perempuan yang seimbang, sehingga hasil studi dapat menunjukkan perbandingan efek pada keduanya.

\section{DAFTAR PUSTAKA}

Antecol, H., \& Cobb-Clark, D. (2006). The Sexual Harassment of Female Active-Duty Personnel: Effects on Job Satisfaction and Intention to Remain in the Military. Journal of Economic Behavior \& Organization, 61(1), 55-80. https://doi.org/10.1016/j.jebo.2004.11.006

Aydogdu, S., \& Asikgil, B. (2011). An Empirical Study of the Relationship Among Job Satisfaction, Organizational Commitment and Turnover Intention. International Review of Management and Marketing. Vol. 1, No. 3 (2011).

Badawy, T. A. E. (2016). An Examination of Sexual Harassment, Job Stress and Turnover Intention: Evidence from Egypt. Journal of Business and Management. Vol No.5 Issue No. 2, December 2016, Page No.11-26.

Carmeli, Abraham, and Jacob Weisberg. "Exploring Turnover Intention among Three Professional Groups of Employees. Human Resource Development International Journal, vol. 9, no. 2, 2006, pp. 191-206., doi:10.1080/13678860600616305.

Cho YJ, Lewis GB. Turnover Intention and Turnover Behavior: Implications for Retaining Federal Employees. Public Personnel Administration Journal. Volume 32 Issue 1, March 2012. doi:10.1177/0734371X11408701

Eller, M. E. (1990). Sexual Harassment in the Hotel Industry: The Need to Focus on Prevention. Hospitality Research Journal, 14(2), 431-440. https://doi.org/10.1177/109634809001400246

Hejase, H. J. (2015). Sexual Harassment in the Workplace: An Exploratory Study from Lebanon. Journal of Management Research, 7(1), 107. https://doi.org/10.5296/jmr.v7i1.6965.

Hutagalung, F., \& Ishak, Z. (2012). Sexual Harassment: A Predictor to Job Satisfaction and Work Stress among Women Employees. Procedia - Social and Behavioral Sciences, 65, 723-730. https://doi.org/10.1016/j.sbspro.2012.11.190

Javier, E.R. (2011). Organizational Spirituality and People Management Practices of Selected Banks in Batangas City: Measures Towards Management Effectiveness, International Journal of Multidisciplinary Research, 2(1): 336-355 
Jehanzeb, K., \& Mohanty, J. (2018). Impact of Employee Development on Job Satisfaction and Organizational Commitment: Person-Organization Fit as moderator. International Journal of Training and Development, 22(3), 171-191. doi:10.1111/ijtd.12127

Jehanzeb, K., Abdul Hamid, A. B., \& Rasheed, A. (2015). What Is the Role of Training and Job Satisfaction on Turnover Intention? International Business Research, 8(3), p208. https://doi.org/10.5539/ibr.v8n3p208

Kirlioğlu, M. and Toygar, Ş. A. (2020). The Effects of Sexual Harassment on Quality of Nurses' Work Life and Turnover Intentions: A sample of Ankara Province. OPUS-International Journal of Society Researches, 16(29), 1613-1627. DOI: 10.26466/opus.775992

Kurnianingsih, S. (2003). Pelecehan Seksual terhadap Perempuan di Tempat Kerja. Buletin Psikologi, 11(2).

Leskinen, E. A., Cortina, L. M., \& Kabat, D. B. (2011). Gender Harassment: Broadening our Understanding of Sex-based Harassment at Work. Law and Human Behavior, 35(1), 25-39. https://doi.org/10.1007/s10979-010-9241-5

Li, N., Zhang, L., Xiao, G., Chen, J., \& Lu, Q. (2019). The Relationship between Workplace Violence, Job Satisfaction and Turnover Intention in Emergency Nurses. International Emergency Nursing, 45, 50-55. doi:10.1016/j.ienj.2019.02.001

Lu Lu, Allan Cheng Chieh Lu, Dogan Gursoy, Nathan Robert Neale, (2016). Work Engagement, Job Satisfaction, and Turnover Intention: A Comparison between Supervisors and Line-level Employees, International Journal of Contemporary Hospitality Management, Vol. 28 Issue: 4, pp.737-761, https:// doi.org/10.1108/IJCHM-07-2014-0360

Lu Y, Hu X-M, Huang X-L, Zhuang X-D, Guo P, Feng L-F, Hu-W, Chen L, Zou H, Hao Y-T, The Relationship between Job Satisfaction, Work Stress, Work- Family Conflict, and Turnover Intention Among Physicians in Guangdong, China: a Cross-Sectional Study. British Medical Journal Open 2017;7:e014894. doi:10.1136/ bmjopen-2016-014894

Luthans, F. (2011). Organizational Behavior. An Evidence-Based Approach (12th ed.). New York: McGraw-Hill International Edition.

Malik, Najma \& Malik, Sadia \& Qureshi, Malik \& Atta, Mohsin. (2014). Sexual Harassment as Predictor of Low Self Esteem and Job Satisfaction among In-Training Nurses. FWU Journal of Social Sciences, Winter 2014, Vol. 8, No.2, 107-116.

Mercer Singapore. (2020). Rethinking Total Rewards During Uncertain Times. Retrieved June 16, 2021, from https://www.mercer.com/content/dam/mercer/attachments/global/webcasts/gl-20202020-compensation-trends-in-asia-pacific-webinar.pdf

Merkin RS, Shah MK. The Impact of Sexual Harassment on Job Satisfaction, Turnover Intentions, and Absenteeism: Findings from Pakistan Compared to the United States. Springerplus. 2014 May 1;3:215. Behavioral Science Journal. doi: 10.1186/2193-1801-3-215.

Mueller, C. W., De Coster, S., \& Estes, S. B. (2001). Sexual Harassment in the Workplace. Journal of Work and Occupations, 28(4), 411-446. doi:10.1177/0730888401028004003

Nazenin, S., \& Palupiningdyah, P. (2014). Peran Stres Kerja dan Kepuasan Kerja untuk Mengurangi Turnover Intention. Jurnal Dinamika Manajemen, 5(2).https://doi.org/10.15294/jdm.v5i2.3663 
Putri Widiana \& Budiono. Pengaruh Sexual Harassment terhadap Turnover Intention melalui Job Satisfaction pada Karyawan Perhotelan di Surabaya

Nurvitasari, A. (2018). Survei 'never OKAY'. Retrieved October 27, 2020, from https://magdalene.co/story/survei-never-okay-81-responden-alami-pelecehan-seksual-ditempat-kerja

O'Connell, C. E., \& Korabik, K. (2000). Sexual Harassment: The Relationship of Personal Vulnerability, Work Context, Perpetrator Status, and Type of Harassment to Outcomes. Journal of Vocational Behavior, 56(3), 299-329. doi:10.1006/jvbe.1999.1717

Parta Yuda, Ida Bagus Dwihana; Ardana, I Komang. Pengaruh Kepuasan Kerja dan Stres Kerja terhadap Turnover Intention pada Karyawan Hotel Holiday Inn Express. E-Jurnal Manajemen, [S.1.], v. 6, n. 10, p. 5319 - 5347, oct. 2017. ISSN 2302-8912

Pranantya, R. A. (2016). Iklim Organisasi dan Sifat Pekerjaan Sebagai Penyebab Terjadinya Pelecehan Seksual dan Pengaruhnya terhadap Motivasi, Stres Kerja, Kepuasan Kerja, serta Kinerja Karyawan. Jurnal Manajemen, 6(1). https://doi.org/10.26460/jm.v6i1.198

Rahim, R. A. (2005). Sexual Harassment of Women Clerical Workers in the Workplace (Doctoral Dissertation, Universiti Putra Malaysia).

Robbins, S.P. 2003. Organizational Behavior. New Jersey. Prentice Hall.

Salman, M., Abdullah, F., \& Saleem, A. (2016). Sexual Harassment at Workplace and its Impact on Employee Turnover Intention. Business \& Economic Review, 8(1), 87-102. https://doi.org/10.22547/BER/8.1.6

Sang Long, C., Lingyun, Z., Owee Kowang, T., Chin Fei, G., \& Wan Ismail, W. K. (2016). The Relationship between Sexual Harassment and Job Satisfaction in the Context of Retailing Industry in China. International Journal of Human Resource Studies, 6(4), 1. doi:10.5296/ijhrs.v6i4.10077

Schneider, K. T., Swan, S., \& Fitzgerald, L. F. (1997). Job-Related and Psychological Effects of Sexual Harassment in the Workplace: Empirical Evidence from Two Organizations. Journal of Applied Psychology, 82(3), 401-415. doi:10.1037/0021-9010.82.3.401

Shah, N. H., \& Jumani, N. B. (2015). Relationship of Job Satisfaction and Turnover Intention of Private Secondary School Teachers. Mediterranean Journal of Social Sciences. doi:10.5901/mjss.2015.v6n4s2p313

Shaw, Jason \& Delery, John \& Jenkins, G. \& Gupta, Nina. (1998). An Organization-Level Analysis of Voluntary and Involuntary Turnover. Academy of Management Journal. 41. 511-525. $10.2307 / 256939$.

Sidharta, N., \& Margaretha, M. (2011). Dampak Komitmen Organisasi dan Kepuasan Kerja terhadap Turnover Intention: Jurnal Manajemen, 14.

Sijabat, J. (2011). Pengaruh Kepuasan Kerja terhadap Komitmen Organisasi dan Keinginan untuk Pindah. Jurnal Visi, 19(3), 592-608.

Sims, C. S., Drasgow, F., \& Fitzgerald, L. F. (2005). The Effects of Sexual Harassment on Turnover in the Military: time-dependent modeling. Journal of Applied Psychology, 90(6), 1141.

Tarigan, Veronica and Ariani, Dorothea Wahyu, (2015), Empirical Study Relations Job Satisfaction, Organizational Commitment, and Turnover Intention, Advances in Management and Applied Economics, 5, issue 2. 
Tella, A. (2007). The Impact of Motivation on Student's Academic Achievement and Learning Outcomes in Mathematics among Secondary School Students in Nigeria. Eurasia Journal of Mathematics, Science and Technology Education, 3(2), 149-156. https://doi.org/10.12973/ejmste/75390

Willness, Chelsea R., et al., A Meta-Analysis of The Antecedents and Consequences of Workplace Sexual Harassment. Personnel Psychology, vol. 60, no. 1, 2007, pp. 127-162., doi:10.1111/j.1744-6570.2007.00067.x.

Witasari, L. (2009). Analisis Pengaruh Kepuasan Kerja dan Komitmen Organisasional terhadap Turnover Intention. Thesis Diterbitkan. Semarang: PPs Universitas Diponegoro Semarang.

Yin-Fah, B. C., Foon, Y. S., Chee-Leong, L., \& Osman, S. (2010). An Exploratory Study on Turnover Intention among Private Sector Employees. International Journal of Business and Management, 5(8). doi:10.5539/ijbm.v5n8p57

Souar Youcef, Setti Sid Ahmed, Boussahmine Ahmed, (2016). The Impact of Job Satisfaction on Turnover Intention by the Existence of Organizational Commitment, and Intent to Stay as Intermediates Variables Using approach PLS in Sample Worker Department of Transport Saida. Journal of Management, 6(6): 198-202. doi: 10.5923/j.mm.20160606.03. 